\title{
ation INTERNATIONAL IOURNAL OF \\ Clear cell carcinoma of the ovary: a clinical and molecular perspective
}
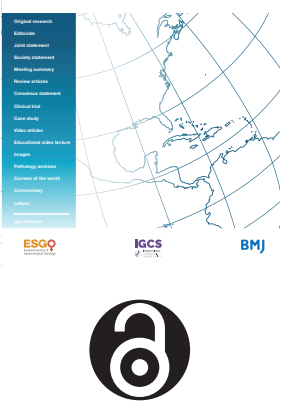

\section{OPEN ACCESS}

'Department of Obstetrics and Gynecology, Jikei University School of Medicine, Tokyo, Japan

${ }^{2}$ University of Edinburgh Cancer Research UK Centre, Edinburgh, UK

Correspondence to

Professor C Simon Herrington, University of Edinburgh Cancer Research UK Centre, Crewe Road, Edinburgh EH4 2XR, UK; simon.herrington@ed.ac.uk

Received 27 May 2020 Revised 13 August 2020 Accepted 17 August 2020 Published Online First 18 September 2020

\author{
Yasushi lida, ${ }^{1}$ Aikou Okamoto, ${ }^{1}$ Robert L Hollis, ${ }^{2}$ Charlie Gourley, ${ }^{2}$ C Simon Herrington (D) ${ }^{2}$
}

\section{ABSTRACT}

Clear cell carcinoma of the ovary has distinct biology and clinical behavior. There are significant geographical and racial differences in the incidence of clear cell carcinoma compared with other epithelial ovarian tumors. Patients with clear cell carcinoma are younger, tend to present at an early stage, and their tumors are commonly associated with endometriosis, which is widely accepted as a direct precursor of clear cell carcinoma and has been identified pathologically in approximately $50 \%$ of clear cell carcinoma cases. The most frequent and important specific gene alterations in clear cell carcinoma are mutations of AT-rich interaction domain 1A (ARID1A) ( $50 \%$ of cases) and phosphatidylinositol-4,5-bisphosphate 3-kinase catalytic subunit alpha (PIK3CA) $(\sim 50 \%$ cases). More broadly, subgroups of clear cell carcinoma have been identified based on C-APOBEC (apolipoprotein B mRNA editing enzyme, catalytic polypeptide-like) and C-AGE (age-related) mutational signatures. Gene expression profiling shows upregulation of hepatocyte nuclear factor 1-beta $(H N F 1 \beta)$ and oxidative stress-related genes, and has identified epithelial-like and mesenchymal-like tumor subgroups. Although the benefit of platinumbased chemotherapy is not clearly defined it remains the mainstay of first-line therapy. Patients with earlystage disease have a favorable clinical outcome but the prognosis of patients with advanced-stage or recurrent disease is poor. Alternative treatment strategies are required to improve patient outcome and the development of targeted therapies based on molecular characteristics is a promising approach. Improved specificity of the histological definition of this tumor type is helping these efforts but, due to the rarity of clear cell carcinoma, international collaboration will be essential to design appropriately powered, large-scale clinical trials.

\section{INTRODUCTION}

Ovarian cancer is a heterogeneous disease and at least five types of epithelial ovarian cancer - high-grade serous, low-grade serous, mucinous, endometrioid, and clear cell carcinomas - are defined at the morphological level, before considering molecular subtypes. ${ }^{1}$ Much of the historical evidence regarding therapeutic efficacy in ovarian carcinoma either identifies histological type based on poorly reproducible criteria or does not distinguish one type from another. ${ }^{2}$ Therefore, much of the evidence regarding ovarian cancer treatment reflects the predominant histological type, which is high-grade serous carcinoma. ${ }^{2}$ However, it is now evident that clear cell carcinoma is a discrete entity, both biologically and clinically, and treatment should be specific for this type. In this review we consider the pathology and clinical behavior of clear cell carcinoma and discuss the extent to which this impacts its management compared with other types of ovarian carcinoma. We also highlight areas where further research is required.

\section{EPIDEMIOLOGY}

In the general population, it is estimated that $1.3 \%$ of women will develop ovarian cancer in their lifetime. ${ }^{3}$ There are significant geographical and racial differences in the incidence of clear cell carcinoma, which is higher in Korea (10.3\%), Taiwan (18.6\%), and Japan $(15 \%-25 \%)^{4-7}$ than in North America and Europe $(1 \%-12 \%) .{ }^{89}$ The reasons for these differences in incidence are not clear, although molecular differences between tumors arising in different populations have been described; these are discussed in the section on molecular pathology. According to Surveillance, Epidemiology, and End Results (SEER) data, in women living in the United States, the proportion of clear cell carcinoma in whites, blacks, and Asians with epithelial ovarian cancer was $4.8 \%, 3.1 \%$, and $11.1 \%$, respectively. ${ }^{10}$ The median age of patients with clear cell carcinoma was significantly younger than that of serous carcinoma of the ovary (55 vs 64 years). ${ }^{10}$ Clear cell carcinoma is often associated with endometriosis, ${ }^{11} 12$ and the presence of endometriosis has been associated with a good prognosis. ${ }^{13}$ Although the molecular mechanisms underlying malignant transformation have not been elucidated fully, endometriosis, particularly ovarian endometriosis, is widely accepted as a direct precursor of endometrioid and clear cell carcinomas of the ovary. ${ }^{14} 15$ This is supported by data showing that women with histologically proven endometriosis have a significantly elevated age-adjusted incidence rate ratio of $2.29(95 \% \mathrm{Cl} 1.24$ to 4.20$)$ for clear cell carcinoma ${ }^{16}$ and by the identification of endometriosis in the final pathology report in $51 \%$ of cases of clear cell carcinoma. ${ }^{17}$ The incidence of thromboembolic complications, such as deep venous thrombosis and pulmonary embolism, is reported to be higher (up to $40 \%$ ) in patients with clear cell carcinoma than in those with other ovarian carcinoma types, ${ }^{18}$ and is considered an independent poor prognostic factor. ${ }^{19} 20$ 


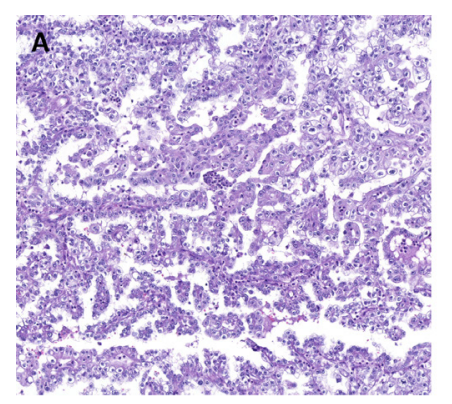

C

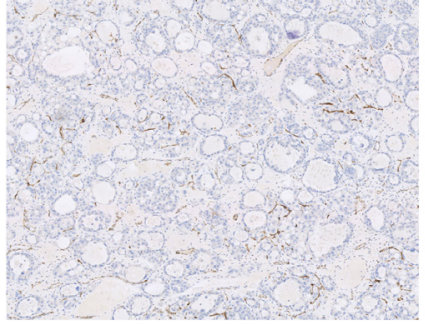

E
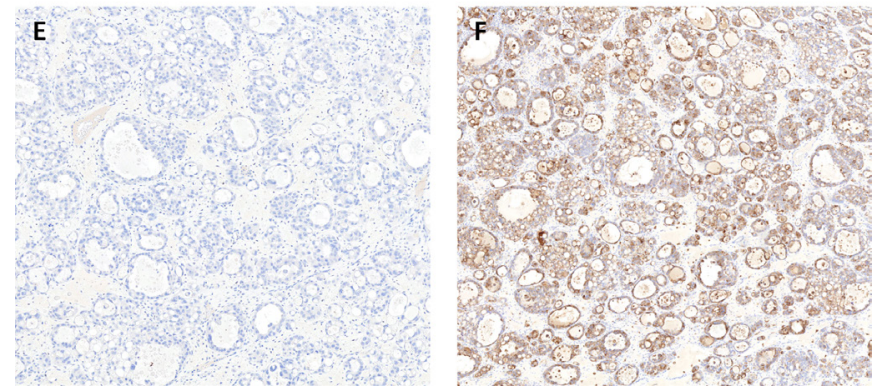

Figure 1 Histopathological features of clear cell carcinoma. Hematoxylin and eosin (H\&E) staining shows (A) papillary and $(B)$ tubulocystic patterns formed by malignant cells with variably clear and eosinophilic cytoplasm. Immunohistochemistry shows a (C) Wilms tumor 1 (WT1)negative, (D) p53 wild-type, (E) estrogen receptor (ER)negative, and $(F)$ napsin A-positive immunoprofile.

Clear cell carcinoma tends to be diagnosed at an earlier stage than serous carcinoma, with $57 \%-81 \%$ and $19 \%-22 \%$, respectively, presenting at stage I or II. ${ }^{81021}$ In early stage, especially stage IA and IC1 (rupture alone) disease, the prognosis of clear cell carcinoma patients is good; 5-year disease-free survival rates of patients with stage IA and IC1 clear cell carcinoma were $84 \%-100 \%$ and $86 \%-89 \%$, respectively. ${ }^{1021-25}$ Stage IB clear cell carcinoma is uncommon and data on the prognosis of stage IB clear cell carcinoma are limited. Chan et al reported a 5year diseasespecific survival of $56.3 \%$ for patients with stage IB clear cell carcinoma, which was significantly lower than other histological types. ${ }^{10}$ A longitudinal analysis reported a median disease-specific survival of only 10.2 months for advanced-stage (International Federation of Gynecology and Oncology (FIGO) III/IV) clear cell carcinoma cases, compared with over 4 years for the overall clear cell carcinoma population. ${ }^{26}$ The prognosis of patients with early-stage clear cell carcinoma is similar to or better than that of patients with serous carcinoma. ${ }^{10}{ }^{27-29} \mathrm{In}$ a review of patients who participated in 12 prospective randomized Gynecologic Oncology Group (GOG) studies, progression-free survival was significantly better in clear cell carcinoma than in serous carcinoma, with a trend towards improved overall survival in stage I and II patients (progression-free survival hazard ratio (HR) $0.69,95 \% \mathrm{Cl} 0.50$ to 0.96 ; overall survival HR $0.76,95 \% \mathrm{Cl} 0.53$ to 1.09$)^{29}$. In a meta-analysis, there was no significant difference in the HR of overall survival between clear cell carcinoma and serous carcinoma in stage I and II patients (HR 0.87, $95 \% \mathrm{Cl} 0.75$ to 1.02 ). ${ }^{30}$ However, in advanced stage, the prognosis of patients with clear cell carcinoma was remarkably poorer than that of patients with serous carcinoma. ${ }^{21}{ }^{29-31}$ In the same review of data from 12 prospective randomized GOG trials, advancedstage clear cell carcinoma had worse progression-free survival and overall survival compared with advanced-stage serous carcinoma (overall survival HR $1.66,95 \% \mathrm{Cl} 1.43$ to 1.91 ). ${ }^{29}$ Furthermore, in the meta-analysis, advanced-stage clear cell carcinoma showed a higher HR for death than serous carcinoma (HR 1.71, 95\% Cl 1.57 to 1.86$).{ }^{30}$ This poorer outcome for patients with advanced-stage clear cell carcinoma has been confirmed in a study based on SEER data. $^{32}$

Recurrence of clear cell carcinoma tends to occur at multiple sites, and Hogan et al reported that 38 of 61 patients with recurrent clear cell carcinoma $(62 \%)$ had multiple-site recurrence involving pelvic, extrapelvic, intrathoracic, lymph node and cere$\mathrm{bral} /$ meningeal sites. ${ }^{33}$ The prognosis of patients with recurrent clear cell carcinoma is poorer than that of patients with recurrent serous carcinoma. ${ }^{34}$. When recurrence occurs at a single site, or is restricted to lymph nodes, survival is longer and disease-free interval can be prolonged by surgery; however, this is based on retrospective data. ${ }^{33}$ This is consistent with the better outcome of patients with isolated lymph node relapse of ovarian carcinoma of all histotypes..$^{35}$ A retrospective study compared 113 patients with recurrent clear cell carcinoma to 365 patients with recurrent serous carcinoma (type not specified) to estimate long-term clinical outcome. The rate of 5-year post-recurrence survival was significantly lower in recurrent clear cell carcinoma than in recurrent serous carcinoma $(13.2 \%$ and $18.2 \%, p<0.0001)$. On multivariable analysis, there was a significant difference in overall survival between patients with recurrent clear cell carcinoma and recurrent serous carcinoma (HR $2.30,95 \% \mathrm{Cl} 1.72$ to $3.07, \mathrm{p}<0.0001$ ). In deceased patients with clear cell carcinoma, $67.8 \%$ and $93.1 \%$ died within 12 and 24 months of recurrence, respectively. In contrast, in deceased patients with serous carcinoma, $40.7 \%$ and $73.0 \%$ died within 12 and 24 months of recurrence, respectively. ${ }^{34}$

\section{DEFINITION AND MOLECULAR PATHOLOGY}

\section{Histopathological Diagnosis}

The diagnostic criteria for clear cell carcinoma have been refined, enabling more robust and reproducible diagnosis of this tumor type. ${ }^{36-38}$ Typical cases have characteristic morphological features, including a combination of papillary, tubulocystic, and solid patterns, combined with clear and eosinophilic cells, and stromal hyalinization. The presence of background endometriosis or clear cell adenofibroma is also helpful in supporting the diagnosis. The recognition that other types of ovarian carcinoma, including highgrade serous carcinoma and endometrioid carcinoma, can contain areas with clear cell change has improved the specificity of a clear cell carcinoma diagnosis, which can now be made using a combination of morphological and immunohistochemical features (Figure 1). In particular, clear cell carcinoma is typically positive 
Table 1 Next-generation sequencing studies

\begin{tabular}{|c|c|c|c|c|c|c|c|}
\hline Author & Year & $\mathbf{n}$ & Tumor site & Stage & Sample & Sequence & Reference \\
\hline Friedlander & 2016 & 105 & N/A & $\mathrm{N} / \mathrm{A}$ & FFPE & 46-gene panel & 45 \\
\hline Wang & 2017 & 35 & Primary & $\mathrm{N} / \mathrm{A}$ & Frozen tissue & $\begin{array}{l}\text { Whole-genome } \\
\text { sequencing }\end{array}$ & 43 \\
\hline Maru & 2017 & 18 & Primary & $\begin{array}{l}\text { I/II } 15(83.3 \%) \\
\text { III/IV } 3(16.7 \%)\end{array}$ & FFPE & 409-gene panel & 49 \\
\hline Elvin & 2017 & 125 & $\begin{array}{l}\text { Primary }(45.6 \%) \\
\text { and metastatic } \\
(54.4 \%)\end{array}$ & N/A & FFPE & $\begin{array}{l}\text { FoundationOne 315-gene } \\
\text { panel }\end{array}$ & 55 \\
\hline Arildsen & 2017 & 10 & Primary & N/A & FFPE & 60-gene panel & 54 \\
\hline Itamochi & 2017 & 55 & Primary & $\begin{array}{l}\text { I/II } 33(60 \%) \\
\text { III/IV } 22(40 \%)\end{array}$ & Frozen tissue & $\begin{array}{l}\text { Whole-genome } \\
\text { sequencing }\end{array}$ & 41 \\
\hline Murakami & 2017 & 39 & Primary & N/A & Frozen tissue & Whole-exome sequencing & 42 \\
\hline Shibuya & 2017 & 48 & Primary & $\begin{array}{l}\text { I/II } 29(60.4 \%) \\
\text { III/IV } 19(39.6 \%)\end{array}$ & FFPE & Whole-exome sequencing & 48 \\
\hline Kim & 2018 & 15 & Primary & $\begin{array}{l}\text { I/II } 11(73.3 \%) \\
\text { III/IV } 4(26.7 \%)\end{array}$ & Frozen tissue & Whole-exome sequencing & 44 \\
\hline Caumanns & 2018 & 124 & Primary & N/A & Frozen tissue & $\begin{array}{l}\text { Kinome sequencing } \\
518 \text { kinases, } 13 \\
\text { diglyceride kinases, } \\
18 \mathrm{PI} 3 \mathrm{~K} \text { domain and } \\
\text { regulatory component } \\
\text { genes, and } 48 \text { cancer- } \\
\text { related genes }\end{array}$ & 127 \\
\hline Takenaka & 2019 & 68 & Primary & $\begin{array}{l}\text { I/II } 19 \text { (27.9\%) } \\
\text { III/IV } 49 \text { 72.0\%) }\end{array}$ & FFPE & 103-gene panel & 51 \\
\hline
\end{tabular}

FFPE, formalin-fixed paraffin-embedded tissue; N/A, not available.

for napsin A and hepatocyte nuclear factor 1-beta (HNF1 $\beta$ ), and negative for Wilms tumor 1 (WT1) and estrogen receptor (ER); high-grade serous carcinoma shows the inverse immunoprofile, and endometrioid carcinoma is negative for napsin A and WT1, and positive for $E R^{36-38}$

\section{Molecular Analyses}

A number of sequencing analyses have been performed in clear cell carcinoma (Table 1). These results and gene alterations previously reported are summarized in Table 2 . The most frequent gene alterations in clear cell carcinoma are in the AT-rich interaction domain $1 \mathrm{~A}$ $(A R I D 1 A)^{39-44}$ and phosphatidylinositol-4,5-bisphosphate 3-kinase catalytic subunit $\alpha(P I K 3 C A)^{39} 41-46$ genes (both occurring in about $50 \%$ of cases).

\section{SWI/SNF Chromatin Remodeling Complex}

ARID1A encodes ARID1A/BAF250A, which is a key component of the switch/sucrose nonfermentable ATP-dependent (SWI/SNF) chromatin remodeling complex that regulates gene expression targeting multiple tumorigenesis pathways ${ }^{47}$. In addition to $A R I D 1 A$ mutation, mutations of $A R I D 1 B(6 \%-18 \%)^{41} 4248$ and SWI/SNF related, matrix associated, actin dependent regulator of chromatin, subfamily a member 4 (SMARCA4) $(5 \%-18 \%)^{41} 49$ affect the SWI/ SNF chromatin remodeling complex.

\section{$\mathrm{PI} 3 \mathrm{~K} / \mathrm{AKT} / \mathrm{mTOR}$ Pathway}

PIK3CA encodes the catalytic subunit $\mathrm{p} 110 \alpha$ of phosphatidylinositol 3-kinase (PI3K). Somatic mutation of PIK3CA increases
PI3K activity and activates the downstream AK strain transforming (AKT) pathway ${ }^{50}$. In addition to PIK3CA mutation, mutations of phosphoinositide-3-kinase regulatory subunit 1 (PIK3R1) $(7 \%-10 \%),{ }^{41-434851}$ mutations of phosphatase and tensin homolog (PTEM $(2 \%-13 \%),{ }^{41-44} 49$ and amplification of AKT serine/threonine kinase 2 (AKT2) $(8 \%-26.6 \%)^{41} 44$ have been reported as genetic changes that affect the PI3K/AKT pathway. ${ }^{50}$

Combined SWI/SNF and PI3K/AKT/mTOR Alterations

An association between loss of ARID1A expression and activation of the PI3K/AKT pathway in clear cell carcinoma has been reported. ${ }^{52}{ }^{53}$ Among 17 clear cell carcinoma cases with PIK3CA mutation, $71 \%$ were found in those with loss of ARID1A protein expression. ${ }^{52}$ Another study showed that the loss of ARID1A expression was more frequent in clear cell carcinoma cases with an activated PI3K/AKT pathway (PIK3CA mutations or loss of PTEN expression) (54\%) than those without activation of the PI3K/AKT pathway $(30 \%)(p=0.046){ }^{53}$ According to studies using nextgeneration sequencing, ARID1A and PIK3CA variants co-occurred in $20 \%-56 \%$ clear cell carcinoma cases, ${ }^{41445455}$ and $82 \%$ of tumors with activation of the PI3K/AKT pathway were observed in tumors with mutations of the SWI/SNF subunit genes. ${ }^{41}$ ARID1A and PIK3CA mutations are likely to occur at an early stage in the development of clear cell carcinoma, as they are also detected in endometriosis, which is considered to be a precursor lesion of clear cell carcinoma. ${ }^{14}$ In a genetically engineered mouse model, loss of ARID1A and activating mutations of PIK3CA were sufficient to 
Table 2 Summary of critical genetic changes in ovarian clear cell carcinoma

\begin{tabular}{|c|c|c|c|}
\hline Gene & Changes & Pathways affected & References \\
\hline$A R I D 1 A$ & Mutation in approximately $50 \%$ & $\begin{array}{l}\text { SWI/SNF chromatin } \\
\text { remodeling complex }\end{array}$ & $39-4448515455127128$ \\
\hline SMARCA4 & Mutation in $5 \%-18 \%$ & $\begin{array}{l}\text { SWI/SNF chromatin } \\
\text { remodeling complex }\end{array}$ & 414849 \\
\hline PIK3R1 & Mutation $7 \%-10 \%$ & PI3K/AKT & $41-434851127128$ \\
\hline AKT2 & Amplification in $8 \%-26 \%$ & PI3K/AKT & 414458128 \\
\hline PTEN & Mutation in $2 \%-13 \%$ & PI3K/AKT & $41-4449127128$ \\
\hline KRAS & Mutation in $4.7 \%-20 \%$ & MAPK & $3941-4548515455127128$ \\
\hline MET & Amplification in $24 \%-37 \%$ & MAPK & 5859 \\
\hline TP53 & Mutation in $8.5 \%-21.6 \%$ & DNA repair & $43-45495155127-129$ \\
\hline TERT promoter & Mutation in 5\%-16\% & TERT & 6162130 \\
\hline ZNF217 & Amplification in $20 \%-36 \%$ & ZNF217 & 656869 \\
\hline
\end{tabular}

Based on Mabuchi et al. ${ }^{131}$

AKT2, AKT serine/threonine kinase 2; ARID1A, AT-rich interactive domain 1A; ARID1B, AT-rich interactive domain 1B; ERBB2, erb-b2 receptor tyrosine kinase 2; GTPase, PPP2R1A, protein phosphatase 2 scaffold subunit A; KRAS, KRAS proto-oncogene; MET, MET protooncogene, receptor tyrosine kinase; PI3K, phosphatidylinositol 3-kinase; PIK3CA, phosphatidylinositol-4,5-bisphosphate 3-kinase catalytic subunit alpha; PIK3R1, phosphoinositide-3-kinase regulatory subunit 1; PTEN, phosphatase and tensin homolog; SMARCA4, SWI/SNFrelated, matrix-associated, actin-dependent regulator of chromatin, subfamily A, member 4; SWI/SNF, switch/sucrose non-fermentable; TERT, telomerase reverse transcriptase; ZNF217, zinc finger protein 217.

generate tumors that phenotypically and molecularly resembled human clear cell carcinoma. ${ }^{56}$

Mitogen-Activated Protein Kinase (MAPK) Pathway Genetic changes in the mitogen-activated protein kinases (MAPK) pathway, such as mutation of protein phosphatase 2 scaffold subunit alpha (PPP2R1A) $(4.1 \%-20 \%)^{39} 42-4457$ and the KRAS proto-oncogene, GTPase (KRAS) (4.7\%-20\%); ${ }^{39} 41-455455$ mutation and amplification of erb-b2 receptor tyrosine kinase 2 (ERBB2) $(4 \%-13 \%) ; 444495455$ and amplification of the MET proto-oncogene (MET) $(24 \%-37 \%)^{58} 59$ have been reported.

TP53, Homologous Recombination Deficiency, and Telomerase Unlike high-grade serous carcinoma, clear cell carcinomas usually express wild-type p53 protein and have a lower frequency of $B R C A 1$ and BRCA2 mutations; ${ }^{41}{ }^{44} B R C A$ mutations have been identified in approximately $6 \%$ ( $1 \%$ germline, $5 \%$ somatic) of cases, and mutations in homologous recombination pathway genes in up to $28 \%$ overall. ${ }^{60}$ The frequency of TP53 mutations in clear cell carcinoma has been reported to be approximately $8.5 \%-21.6 \% .{ }^{43-45} 4955$ It is possible, however, that some of the TP53 and BRCA1-mutated carcinomas categorized as clear cell carcinoma in these cohorts are high-grade serous carcinomas with areas of clear cell change. Clear cell carcinoma has a higher frequency of telomerase reverse transcriptase (TERT) promoter mutation $(5.7 \%-16.0 \%)$ than other histological types of epithelial ovarian cancer. ${ }^{61} 62$ TERT promoter mutation does not appear to be an early event in the carcinogenesis of clear cell carcinoma, as it was not observed in endometriosis progressing to clear cell carcinoma. ${ }^{61}$

\section{Mutational Signatures}

Two major subgroups of clear cell carcinoma have been identified based on mutational signatures: C-APOBEC, characterized by an apolipoprotein B mRNA editing enzyme, catalytic polypeptide-like (APOBEC) mutation signature (26\%), and C-AGE, characterized by an age-related (AGE) mutation signature $(40 \%) .{ }^{43}$ Consistent with this, another study reported an APOBEC signature in $18 \%$ of clear cell carcinoma. ${ }^{48}$ The APOBEC mutational process has been proposed as a therapeutic target to prevent ongoing clonal evolution in disease progression. ${ }^{63} \mathrm{~A}$ multi-region sequencing study showed APOBEC-mediated kataegis to be an early event in clear cell carcinoma development, with APOBEC3B expression associated with infiltration by cytotoxic $T$ cells and favorable outcome. Moreover, in another study, APOBEC3B overexpression was shown to associate with improved clinical outcome in clear cell carcinoma and to have a potential role in predicting response to platinumbased chemotherapy. ${ }^{64}$

\section{Copy-Number Alterations}

The total number of copy-number alterations in clear cell carcinoma is similar to that in low-grade serous carcinoma, ${ }^{65}$ and much lower than in high-grade serous carcinoma ${ }^{6566}$ Conversely, the ratio of whole-arm copy-number alterations in clear cell carcinoma was significantly higher than in serous carcinoma. ${ }^{66}$ Whole-arm 


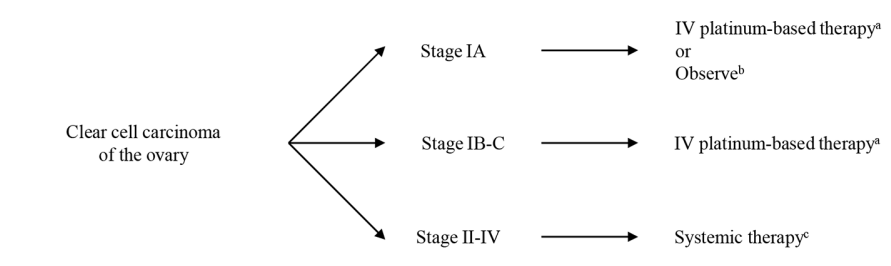

\begin{tabular}{|c|c|c|}
\hline Preferred Regimens & Other Recommended Regimens & Useful in Certain Circumstances \\
\hline - Paclitaxel 175/carboplatin & $\begin{array}{l}\text { - Carboplatin/liposomal doxorubicin } \\
\text { - Docetaxel/carboplatin }\end{array}$ & $\begin{array}{l}\text { Carboplatin (if elderly [age }>70 \text { ] and/or for those with } \\
\text { comorbidities) }\end{array}$ \\
\hline \multicolumn{3}{|c|}{${ }^{\mathrm{b}}$ Consider surgical staging (if not previously done) if considering observation } \\
\hline \multicolumn{3}{|l|}{${ }^{\circ}$ Primary Systemic Therapy Regimens for Stage II-IV Disease } \\
\hline Preferred Regimens & Other Recommended Regimens & Useful in Certain Circumstances \\
\hline $\begin{array}{l}\text { - Paclitaxel } 175 / \text { carboplatin } \\
\text { Paclitaxel/carboplatin/bevacizumab + maintenance } \\
\text { bevacizumab }\end{array}$ & $\begin{array}{ll}\text { - } & \text { Paclitaxel weekly/carboplatin weekly } \\
\text { - } & \text { Docetaxel/carboplatin } \\
\text { - } & \text { Pachoplatin/linel weekly/carboplatin q3weeks }\end{array}$ & $\begin{array}{l}\text { - IP/IV paclitaxel/cisplatin (for optimally debulked stage } \\
\text { II-III disease) }\end{array}$ \\
\hline
\end{tabular}

Figure 2 National Comprehensive Cancer Network (NCCN) guidelines version 1.2020 for clear cell carcinoma of the ovary. ${ }^{87}$ IP, intraperitoneal; IV, intravenous.

copy-number alterations at $8 \mathrm{q}$ in clear cell carcinoma were also reported in other studies. ${ }^{42}{ }^{67}$ The most remarkable region with copy-number gain in clear cell carcinoma is at chr20q13.2, which includes a potential oncogene, zinc finger protein 217 (ZNF217), at a frequency of 20\%-36\%. ${ }^{6568} 69$ ZNF217 was amplified significantly more frequently in Japanese (62\%) than in Korean $(7 \%)$ or German (25\%) clear cell carcinoma, ${ }^{67}$ and high-level amplification of ZNF217 was identified in C-APOBEC (33\%) and C-AGE (57\%) tumors. ${ }^{43}$ Moreover, ZNF217 amplification in clear cell carcinoma correlated significantly with shorter progression-free survival ( $H R$ 2.6, $95 \% \mathrm{Cl} 1.1$ to $6.1, \mathrm{p}=0.339$ ) and overall survival (HR 3.5, $95 \% \mathrm{Cl} 1.1$ to $10.6, \mathrm{p}=0.031) .^{68}$ The association between ZNF217 and SWI/SNF is controversial. Loss of ARID1A expression has been reported to be coincident with PI3K-AKT pathway activation and/ or ZNF217 amplification. ${ }^{53}$ Conversely, in another study, the cases positive for all SWI/SNF subunits demonstrated significantly greater DNA copy-number alterations, such as amplification of chromosomes 20q.13.2-20q13.33 (including ZNF217) and 8q.24.3, and deletion of chromosomes 13q12.11-13q14.3 (including RB1), 17p13.2-17 p13.1 (including TP53), and 19p13.2-19p13.12. ${ }^{70}$

\section{Transcriptomic Analyses}

Previous microarray analyses have identified a clear cell carcinoma expression profile that is distinct from other histological types of ovarian carcinoma ${ }^{67172}$ HNF1 $\beta$ and oxidative stress-related genes are upregulated in clear cell carcinoma. ${ }^{73}$ Microarray analysis classified clear cell carcinoma into three clusters, and co-existent alterations of PIK3CA and ARID1A were commonly observed in two of these $(7 / 11,64 \%)$ but not in the third $(0 / 10,0 \% ; p<0.01)$. Being in the cluster without co-existent PIKCA and ARID1A alteration was an independent favorable prognostic factor. ${ }^{66}$ Unsupervised gene expression analysis of clear cell carcinoma has identified two gene transcriptomic subtypes associated with differential outcome, termed epithelial- and mesenchymal-like. ${ }^{75}$ The epithelial-like subgroup, which had a high frequency of SWI/SNF complex mutations, was associated with early stage at diagnosis and favorable outcome, while the mesenchymal-like group was enriched for advanced-stage disease at diagnosis and overall poor prognosis.

\section{CLINICAL ASPECTS}

\section{Diagnosis}

As described above, the morphological features of clear cell carcinoma are often typical and diagnostic; and the addition of immunohistochemistry for WT1, p53, napsin A, and HNF1 $\beta$ helps to ensure diagnostic specificity by allowing the exclusion of, in particular, high-grade serous carcinoma with clear cells. ${ }^{36-38} 70$ It is important that clear cell carcinoma is defined robustly both in clinical practice and in molecular and clinical studies to ensure that patients are managed appropriately, and therapeutic responses and outcomes are accurately determined.

\section{Surgery}

Tumor stage is an important determinant of outcome and is crucial for clinical management. Lymphadenectomy is necessary to determine the precise stage because the rate of lymph node metastasis has been reported to be $4.5 \%-14.4 \%$ in pT1 (tumor limited to ovaries (one or both)) or pT2 (tumor involving one or both ovaries with pelvic extension) clear cell carcinoma. ${ }^{2276-78}$ In the Multicentre Italian Trials in Ovarian Cancer (MIT0-9) retrospective study, diseasefree survival was longer in patients undergoing lymphadenectomy at surgery, both in early-stage $(p=0.026)$ and in advanced-stage $(p=0.004)$ disease. Lymphadenectomy was independently associated with longer overall survival ( $\mathrm{HR} 0.15,95 \% \mathrm{Cl} 0.04$ to 0.54 ) in multivariate analysis, ${ }^{79}$ although stage shift is clearly a possible confounding factor in this study. Other studies have failed to show the therapeutic benefit of lymphadenectomy for early-stage clear cell carcinoma $\mathrm{a}^{237678}$ and further studies are required to determine the impact of lymphadenectomy in this context.

Although it has been reported that residual disease after cytoreductive surgery is a strong predictor of survival in advanced-stage epithelial ovarian cancer, the proportion of clear cell carcinomas 


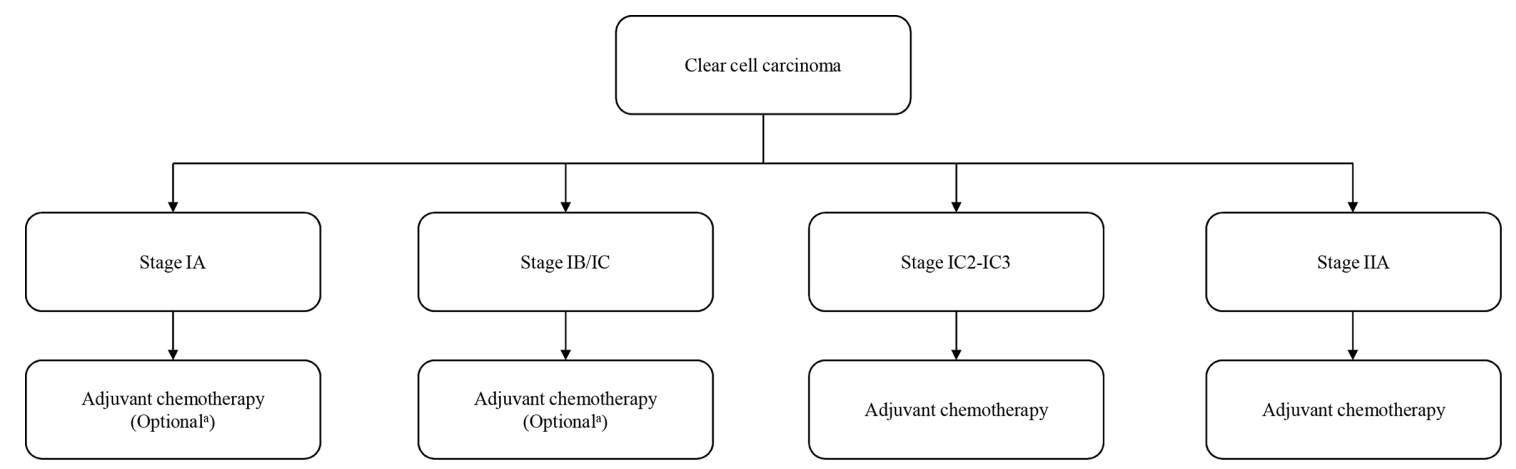

Figure 3 Adjuvant chemotherapy for patients with early-stage clear cell ovarian cancer (stage I-IIA). From European Society for Medical Oncology-European Society of Gynaecological Oncology (ESMO-ESGO) consensus conference recommendations on ovarian cancer. ${ }^{89}$ No adjuvant chemotherapy should be considered only for patients with complete surgical staging.

in these reports is low $(3.3 \%-4.8 \%){ }^{31}{ }^{80-82}$ There are, however, a few reports that examine an association between residual tumor and prognosis in clear cell carcinoma. Takano et al performed a retrospective analysis to evaluate the clinical characteristics and prognostic factors in the 254 patients with clear cell carcinoma of the ovary. There was no significant prognostic difference between patients with residual tumor diameter $<1 \mathrm{~cm}$ and those with residual tumor diameter $>1 \mathrm{~cm}(\mathrm{p}=0.40)$. Patients with no residual tumor had significantly better progression-free survival than those with residual tumor $<1 \mathrm{~cm}(\mathrm{p}=0.04)$ or those with residual tumor diameter $>1 \mathrm{~cm}(\mathrm{p}<0.01)$, and only residual tumor diameter was an independent prognostic factor in advanced-stage clear cell carcinoma $(p=0.02) .{ }^{22}$ Furthermore, Melamed et al conducted a retrospective cohort study to quantify the magnitude of associations between residual disease status and all-cause mortality by histological type using data from the National Cancer Database of America. Overall survival differed significantly according to residual disease status not only in patients with high-grade serous carcinoma but also in those with clear cell carcinoma and, while not statistically significantly different, the survival benefit associated with cytoreduction to no residual disease was greater in clear cell carcinoma ( $\mathrm{HR} 0.39,95 \% \mathrm{Cl} 0.22$ to 0.69 ) than in high-grade serous carcinoma (HR $0.58,95 \% \mathrm{Cl} 0.49$ to 0.68 ). ${ }^{83}$ Surgery to achieve no residual tumor may be necessary to improve the prognosis in advanced-stage clear cell carcinoma.

As clear cell carcinoma is found at early stage and at a younger age, fertility sparing is an important consideration in clinical practice. According to a summary of studies on fertility-sparing surgery in stage I clear cell carcinoma, there was no difference in the recurrence rate between patients with clear cell carcinoma and nonclear cell carcinoma $(7 / 53,13.2 \%$ and $41 / 377,10.9 \%$; $p=0.61){ }^{84}$ However, in another report, the recurrence rate of stage IC clear cell carcinoma patients who underwent fertility-sparing surgery was $22.5 \%(7 / 31){ }^{85}$ The role for fertility-sparing surgery in stage $1 \mathrm{~B}$ is unclear from existing data. Therefore, fertility-sparing surgery may be an option at least for patients with stage IA clear cell carcinoma when adequate staging is conducted. A recent systematic review supports this conclusion, identifying that fertility sparing surgery is not associated with worse survival in patients with stage I disease. ${ }^{86}$

\section{Chemotherapy}

Current National Comprehensive Cancer Network (NCCN) guidelines for the management of clear cell carcinoma are summarized in Figure $2{ }^{87}$ Although previous NCCN guidelines recommended adjuvant chemotherapy for clear cell carcinoma regardless of disease stage ${ }^{88}$ current European Society for Medical Oncology-European Society of Gynaecological Oncology (ESMO-ESGO) consensus conference recommendations on ovarian cancer indicate that the benefit of adjuvant chemotherapy is uncertain for patients with stage IA, IB, and IC1 clear cell carcinoma, and no adjuvant chemotherapy is recommended for patients with stage IA, IB, and IC1 clear cell carcinoma with complete surgical staging (Figure 3). ${ }^{89}$ The current NCCN ovarian cancer guidelines also state that observation is an option for patients with IA clear cell carcinoma who have undergone complete surgical staging (Figure 2). ${ }^{87}$ The subset analysis in the ACTION study showed similar progression-free survival for patients with stage I-IIA clear cell carcinoma with or without adjuvant chemotherapy, ${ }^{90}$ and two retrospective analyses reported no benefit for adjuvant chemotherapy after complete surgical staging for stage IA-B clear cell carcinoma. ${ }^{91}{ }^{92}$ Furthermore, a large-scale study based on SEER data revealed that there was no significant difference in 5-year overall survival between the patients with stage I clear cell carcinoma who received adjuvant chemotherapy (85\%) and those who did not $(83 \%)(p=0.43)$. This was also true for substage IC clear cell carcinoma, where there was no significant difference in 5-year overall survival between the patients who received adjuvant chemotherapy (83\%) and those who did not $(80 \%)(p=0.62) .^{93}$ However, a systematic review and meta-analysis identified that adjuvant chemotherapy correlated with improved overall survival in patients with stage IC (odds ratio (OR) $0.70,95 \% \mathrm{Cl} 0.52$ to 0.93 ) but not stage IA or IB disease. ${ }^{94}$

A study of 210 patients showed that there was no impact of three versus six cycles of chemotherapy on overall survival in earlystage clear cell carcinoma. ${ }^{95}$ Further studies of early-stage disease are required to determine which stages of disease benefit from chemotherapy and how many cycles of adjuvant chemotherapy are appropriate. At present, the Japanese Gynecologic Oncology Group (JGOG) is performing a randomized phase III trial to evaluate the necessity of adjuvant chemotherapy in stage I epithelial ovarian cancer (stage IA/IB clear cell carcinoma or grade $2 / 3$ other histological type and stage IC1 with all grades and histological types) after comprehensive staging surgery (JGOG3020, UMIN000008481). It 
Table 3 Clinical trials of clear cell carcinoma using molecular targeted therapy

\begin{tabular}{|c|c|c|c|c|c|c|}
\hline Study title & Status & Conditions & Interventions & Phase & Target & $\begin{array}{l}\text { ClinicalTrials.gov } \\
\text { identifier }\end{array}$ \\
\hline GOG-0268 & Completed & $\begin{array}{l}\text { Newly } \\
\text { diagnosed stage } \\
\text { III or IV OCCC }\end{array}$ & $\begin{array}{l}\text { Temsirolimus, } \\
\text { carboplatin, and } \\
\text { paclitaxel }\end{array}$ & II & mTOR & NCT01196429 \\
\hline GOG-0254 & Completed & $\begin{array}{l}\text { Persistent or } \\
\text { recurrent OCCC }\end{array}$ & Sunitinib & II & $\begin{array}{l}\text { PDGFRs and } \\
\text { VEGFRs }\end{array}$ & NCT00979992 \\
\hline NRG-GY001 & Completed & $\begin{array}{l}\text { Persistent or } \\
\text { recurrent OCCC }\end{array}$ & Cabozantinib & II & $\begin{array}{l}\text { MET, RET, } \\
\text { VEGFR2, and } \\
\text { AXL }\end{array}$ & NCT02315430 \\
\hline $\mathrm{NiCCC}$ & Recruiting & $\begin{array}{l}\text { Persistent or } \\
\text { recurrent OCCC } \\
\text { and endometrial } \\
\text { CCC }\end{array}$ & Nintendanib & II & $\begin{array}{l}\text { FGFRs, } \\
\text { PDGFRs, and } \\
\text { VEGFRs }\end{array}$ & NCT02866370 \\
\hline MOCCA & Recruiting & $\begin{array}{l}\text { Persistent or } \\
\text { recurrent OCCC }\end{array}$ & Durvalumab & II & PD-L1 & NCT03405454 \\
\hline BrUOG 354 & Recruiting & $\begin{array}{l}\text { Persistent or } \\
\text { recurrent OCCC } \\
\text { or extra-renal } \\
\text { origin CCC }\end{array}$ & $\begin{array}{l}\text { Nivolumab } \pm \\
\text { ipilimumab }\end{array}$ & II & PD-1, CTLA4 & NCT03355976 \\
\hline
\end{tabular}

AURKA, aurora kinase A; CCC, clear cell carcinoma; CTLA4, cytotoxic T-lymphocyte-associated protein 4; FGFR, fibroblast growth factor receptor; FIt3, FMS-like tyrosine kinase; IDO1, idoleamine 2,3-dioxygenase-1; MET, MET proto-oncogene, receptor tyrosine kinase; mTOR, mammalian target of rapamycin; OCCC, ovarian clear cell carcinoma; PD-1, programmed cell death 1; PDGF, platelet-derived growth factor; PDGFR, platelet-derived growth factor receptor; PD-L1, programmed cell death 1 ligand; RET, RET proto-oncogene, receptor tyrosine kinase; VEGFR, vascular endothelial growth factor receptor.

is hoped that this trial will shed more light on the role of chemotherapy in stage IA/IC1 clear cell carcinoma.

In first-line chemotherapy for clear cell carcinoma, the response rate to a combination of paclitaxel plus platinum, which is standard therapy for ovarian carcinoma, is thought to be higher $(22 \%-56 \%)$ than that of other platinum-based chemotherapy $(11 \%-27 \%)^{21}{ }^{22} 96-99$ However, the addition of taxane was not an independent prognostic factor in the MIT0-9 study, ${ }^{79}$ and there was no survival benefit in advanced-stage clear cell carcinoma between patients treated with paclitaxel plus platinum compared with those treated with platinum monotherapy in a large Japanese study. ${ }^{22}$ A randomized phase III study of paclitaxel and carboplatin versus dose-dense paclitaxel and carboplatin as a first-line treatment for stage II-IV epithelial ovarian cancer showed that dose-dense paclitaxel and carboplatin offers better survival than paclitaxel and carboplatin in ovarian cancers unselected for histological type. ${ }^{100}$ However, in subgroup analysis of this study, there was no significant survival benefit in patients with clear cell or mucinous tumors between treatment groups. ${ }^{100}$ Conversely, combination therapy with irinotecan hydrochloride and cisplatin has been reported to be effective as first-line and second-line chemotherapy for clear cell carcinoma. $^{101} 102$

A randomized phase II study (JGOG3014) to compare combination therapy with irinotecan hydrochloride and cisplatin and paclitaxel/carboplatin revealed that completion rates of six cycles and 5 -year progression-free survival were similar in both arms. ${ }^{103} \mathrm{~A}$ subsequent randomized phase III study of combination therapy with irinotecan hydrochloride and cisplatin versus paclitaxel/carboplatin as first-line treatment for clear cell carcinoma was conducted by the JGOG in collaboration with the Gynecologic Cancer Intergroup (GCIG; JG0G3017/GCIG Trial). However, there was no significant survival benefit with combination therapy with irinotecan hydrochloride and cisplatin; 2-year progression-free survival rates were $73.0 \%$ in the combination therapy with irinotecan hydrochloride and cisplatin group and $77.6 \%$ in the paclitaxel/carboplatin group (HR $1.17,95 \% \mathrm{Cl} 0.87$ to 1.58$).{ }^{104}$

In second-line or salvage chemotherapy, the response rate for recurrent or refractory clear cell carcinoma is extremely 


\section{Review}

Table 4 Possible individualized investigational approaches to the treatment of metastatic or recurrent clear cell ovarian cancer.

\begin{tabular}{llll}
\hline Molecular subgroup & Target & Possible agent(s) & Additional comments \\
\hline ARID1A mutant tumors & DDR pathway & ATR inhibitors & ( \\
& Histone deacetylase & HDAC inhibitors & \\
& Zeste homolog 2 & EZH2 inhibitor & \\
PI3K/AKT/mTOR activated & PI3K/AKT/mTOR pathway & PI3K/mTOR/TORC inhibitors & \\
MAPK pathway activated & MAPK pathway & RAS/RAF/MEK inhibitors & $\begin{array}{l}\text { Inhibitor choice mutation- } \\
\text { dependent }\end{array}$ \\
Mismatch repair deficient & PD1/PD-L1 & PD1/PD-L1 inhibitors & $\begin{array}{l}\text { May require to be part of } \\
\text { basket study }\end{array}$ \\
$\begin{array}{l}\text { Mesenchymal-type gene } \\
\text { expression profile }\end{array}$ & Angiogenic pathways & VEGF monoclonal antibodies and & \\
\hline
\end{tabular}

ATR, ataxia telangiectasia and Rad3-related protein; DDR, DNA damage response; EZH2, Zeste homolog 2; HDAC, histone deacetylase; MAPK, mitogen-activated protein kinase; mTOR, mammalian target of rapamycin; PARP, poly-ADP ribose polymerase; PD1, programmed cell death protein 1; PD-L1, programmed death ligand 1; TORC, mammalian target of rapamycin complex; VEGF, vascular endothelial growth factor; VEGFR, vascular endothelial growth factor receptor.

low. ${ }^{9697105-108}$ In a large-scale study of platinum-sensitive relapsed ovarian carcinoma, including all histological types, the response rates of patients treated with paclitaxel plus platinum chemotherapy and those with other platinum-based chemotherapy were $66 \%$ and $54 \%$, respectively. ${ }^{109}$ However, even in patients with 'platinumsensitive' relapsed clear cell carcinoma, the response rate was lower than $10 \% .{ }^{105} 106$ In a retrospective study of 75 patients with recurrent or refractory clear cell carcinoma, the median overall survival of patients after platinum-sensitive or platinum-resistant relapse were 16 months and 7 months, respectively $(p=0.04) .{ }^{106}$ Chemotherapy for recurrent or refractory clear cell carcinoma therefore has only small benefit, especially in platinum-resistant relapse.

\section{Radiotherapy}

Adjuvant radiotherapy may improve the prognosis of early-stage clear cell carcinoma. In a retrospective analysis of stage IC, II, and III clear cell carcinoma to compare chemotherapy (cyclophosphamide, adriamycin, and cisplatin) and whole abdominal radiotherapy, overall survival and disease-free survival were significantly superior in the whole abdominal radiotherapy group to those in the chemotherapy group. ${ }^{110}$ Furthermore, a large-scale retrospective analysis of 241 patients with stage I and II clear cell carcinoma to compare adjuvant chemotherapy (three-cycle paclitaxel/carboplatin) followed by radiation (22.5 Gy to pelvis followed by $22.5 \mathrm{~Gy}$ to the whole abdomen) and chemotherapy (six-cycle paclitaxel/ carboplatin) only, there was a significant improvement in diseasefree survival by $20 \%$ at 5 years within stage IC (all IC patients except those who were IC by virtue of rupture alone) and stage II. ${ }^{25}$ Conversely, in a more recent retrospective study of 163 patients with stage I and II clear cell carcinoma, adjuvant radiotherapy was not significantly associated with increased progression-free or overall survival either in the whole group or even in the high-risk group (stage IC2, IC3, and II). ${ }^{111}$ The latter study was more likely to be subject to selection bias than the former as, in the former study, the decision to treat with chemo-radiotherapy or chemotherapy alone was based on service factors rather than patient factors.
Further research is needed to determine the benefit of radiotherapy in early-stage clear cell carcinoma.

Radiotherapy may have a role in the treatment of patients with locoregionally recurrent clear cell carcinoma. ${ }^{112}{ }^{113}$ One retrospective study of involved-field radiation therapy found higher 5 -year overall survival $(88 \%$ vs $37 \%, p=0.05)$ and disease-free survival ( $75 \%$ vs $20 \%, p=0.01$ ) in eight patients with clear cell carcinoma compared with other histological types. ${ }^{114}$

\section{Targeted Therapy}

Some agents targeting angiogenesis (bevacizumab, sunitinib, nintendanib), the PI3K/AKT/mTOR pathway (temusirolimus), immune checkpoints (nivolumab, durvalumab), loss of BAF250a (dasatinib), Aurora A (ENMD-2076), and MET (cabozantanib) are currently being evaluated in clinical trials, either as monotherapy or in combination with other targeted/cytotoxic agents (Table 3).

Bevacizumab was the first targeted therapy to receive the approval of the European Medicine Agency for the treatment of epithelial ovarian cancer. ICON7, a phase III randomized study, assessed bevacizumab combined with carboplatin and paclitaxel in the upfront setting compared with carboplatin and paclitaxel alone. This study included patients with stage I or IIA clear cell carcinoma and no benefit of bevacizumab was reported for clear cell carcinoma in a subgroup analysis, ${ }^{115}$ although this analysis was very underpowered and cannot be taken as evidence for absence of an effect of bevacizumab in clear cell ovarian carcinoma. The vascular endothelial growth factor receptor (VEGFR) inhibitor sunitinib demonstrated minimal activity in a phase II trial of patients with recurrent clear cell carcinoma as the second- or third-line treatment, with a response rate of $6.7 \%{ }^{116}$

Temsirolimus, an inhibitor of mammalian target of rapamycin (mTOR), was evaluated in a phase II trial in combination with carboplatin and paclitaxel as first-line therapy in the treatment of stage III-IV clear cell carcinoma of the ovary. This regimen did not statistically significantly increase progression-free survival compared with historical control. ${ }^{117}$ In a study of nivolumab, an immune checkpoint inhibitor that blocks programmed cell death 1 (PD-1), 
for platinum-resistant ovarian carcinoma, one of two patients with clear cell carcinoma exhibited complete response and, in a study of avelumab for recurrent/refractory ovarian carcinoma, both patients with clear cell carcinoma exhibited partial response. ${ }^{118}{ }^{119}$ Immune checkpoint inhibitors may represent a new treatment option for clear cell carcinoma, and clinical trials using these are ongoing.

ENMD-2076, an oral multitarget kinase selective against Aurora $A$ and VEGFR, was evaluated for its activity in patients with recurrent ovarian clear cell carcinoma in a phase II study. The overall 6 -month progression-free survival rate was $22 \%$ and did not meet the preset threshold for efficacy. ${ }^{120}$ Besides these agents, it has been reported that a histone deacetylase (HDAC) inhibitor and an enhancer of zeste homologue 2 (EZH2) inhibitor selectively suppressed the growth of ARID1A-mutated cells in vitro and in vivo, ${ }^{121} 122$ and these drugs are expected to be introduced into clinical trials. In a small study, high HDAC6 expression correlated with poor prognosis in clear cell carcinoma with ARID1A loss, and also with programmed death-ligand 1 (PD-L1) expression. ${ }^{123}$ This is consistent with the demonstration that HDAC6 inhibition can synergize with anti-PD-L1 therapy in a mouse model, raising the possibility that this combination may represent a novel therapeutic strategy. ${ }^{124}$

In early work, prolyl hydroxylase domain-containing protein 2 (PHD2), encoded by EGLN1, has been identified as a potential hypoxia-inducible factor $1 \alpha$ (HIF1A)-dependent therapeutic target in clear cell carcinoma ${ }^{125}$ and screening of ARID1A-deficient cells has suggested that gemcitabine may be an effective therapeutic option in ARID1A-deficient tumors. ${ }^{126}$

\section{Post-Treatment Surveillance}

Current NCCN guidelines do not recommend clear cell carcinomaspecific post-treatment surveillance ${ }^{87}$ patients are followed up in the same way as patients with other histological tumor types. However, the ESMO-ESGO consensus conference recommendations on ovarian cancer indicate that $\mathrm{CA} 125$ is not a reliable marker in epithelial ovarian carcinoma types other than high-grade serous carcinoma. ${ }^{89}$

\section{Future Directions}

The improved definition of ovarian clear cell carcinoma, and greater understanding of its molecular characteristics, provide opportunities to develop alternative treatment strategies with the aim of improving survival, particularly of patients with advancedstage or recurrent disease. Possible individualized investigational approaches based on tumor biology are suggested in Table 4. Due to the rarity of clear cell carcinoma, international collaboration will be essential to power large-scale clinical trials required to answer the many remaining questions regarding the optimal treatment of this disease. Accurate diagnosis, particularly the exclusion of clear cell carcinoma mimics such as high-grade serous carcinoma with clear cells, will be crucial for these trials to produce reliable findings. Specific areas that merit further investigation include the relationship between mismatch repair (MMR) deficiency and response to immune checkpoint inhibitors, the prevalence of $B R C A$ mutation and its relationship to poly-ADP ribose polymerase (PARP) inhibitor response, and the development of novel therapies based on tumor biology.
Correction notice This article has been corrected since it was published Online First. The author name Robert L Hollis was incorrectly written as Robb Hollis. This has now been amended.

Acknowledgements The authors would like to extend their thanks to the Nicola Murray Foundation for their generous support of the authors' laboratory, and the NHS Lothian Department of Pathology.

Contributors YI drafted the manuscript. CSH provided the figure. A0, RLH, CG, and $\mathrm{CSH}$ reviewed and edited the manuscript. All authors approved the submitted version.

Funding RLH is supported by Target Ovarian Cancer and the Medical Research Council (MRC). This work was also supported by a charitable donation from the Nicola Murray Foundation and by Cancer Research UK.

Competing interests CG discloses the following: research funding from AstraZeneca, Aprea, Nucana, Tesaro, and Novartis; honoraria/consultancy fees from Roche, AstraZeneca, Tesaro, Nucana, MSD, Clovis, Foundation One, Sierra Oncology, and Cor2Ed; named on issued/pending patents relating to predicting treatment response in ovarian cancer beyond the scope of this work.

Patient consent for publication Not required.

Provenance and peer review Not commissioned; externally peer reviewed.

Open access This is an open access article distributed in accordance with the Creative Commons Attribution 4.0 Unported (CC BY 4.0) license, which permits others to copy, redistribute, remix, transform and build upon this work for any purpose, provided the original work is properly cited, a link to the licence is given, and indication of whether changes were made. See: https://creativecommons.org/ licenses/by/4.0/.

ORCID iD

C Simon Herrington http://orcid.org/0000-0001-9177-8165

\section{REFERENCES}

1 Prat J, D'Angelo E, Espinosa I. Ovarian carcinomas: at least five different diseases with distinct histological features and molecular genetics. Hum Pathol 2018;80:11-27.

2 Gourley C, Bookman MA. Evolving concepts in the management of newly diagnosed epithelial ovarian cancer. J Clin Oncol 2019;37:2386-97.

3 Kvaskoff M, Horne AW, Missmer SA. Informing women with endometriosis about ovarian cancer risk. Lancet 2017;390:2433-4.

$4 \mathrm{Kim} \mathrm{SI}$, Lim MC, Lim J, et al. Incidence of epithelial ovarian cancer according to histologic subtypes in Korea, 1999 to 2012. J Gynecol Oncol 2016;27:e5.

5 Chiang Y-C, Chen C-A, Chiang C-J, et al. Trends in incidence and survival outcome of epithelial ovarian cancer: 30-year national population-based registry in Taiwan. J Gynecol Oncol 2013;24:342-51.

6 Okamoto A, Glasspool RM, Mabuchi S, et al. Gynecologic Cancer Intergroup (GCIG) consensus review for clear cell carcinoma of the ovary. Int J Gynecol Cancer 2014;24:S20-5.

7 Yahata T, Banzai C, Tanaka K, et al. Histology-specific long-term trends in the incidence of ovarian cancer and borderline tumor in Japanese females: a population-based study from 1983 to 2007 in Niigata. J Obstet Gynaecol Res 2012;38:645-50.

8 Köbel M, Kalloger SE, Huntsman DG, et al. Differences in tumor type in low-stage versus high-stage ovarian carcinomas. Int $J$ Gynecol Pathol 2010;29:203-11.

9 Mackay HJ, Brady MF, Oza AM, et al. Prognostic relevance of uncommon ovarian histology in women with stage III/IV epithelial ovarian cancer. Int J Gynecol Cancer 2010;20:945-52.

10 Chan JK, Teoh D, Hu JM, et al. Do clear cell ovarian carcinomas have poorer prognosis compared to other epithelial cell types? A study of 1411 clear cell ovarian cancers. Gynecol Oncol 2008;109:370-6.

11 Wentzensen N, Poole EM, Trabert B, et al. Ovarian cancer risk factors by histologic subtype: an analysis from the Ovarian Cancer Cohort Consortium. J Clin Oncol 2016;34:2888-98.

12 Pearce CL, Templeman C, Rossing MA, et al. Association between endometriosis and risk of histological subtypes of ovarian cancer: a pooled analysis of case-control studies. Lancet Oncol 2012;13:385-94.

13 Lee HY, Hong JH, Byun JH, et al. Clinical characteristics of clear cell ovarian cancer: a retrospective multicenter experience of 308 patients in South Korea. Cancer Res Treat 2020;52:277-83. 
14 Anglesio MS, Bashashati A, Wang YK, et al. Multifocal endometriotic lesions associated with cancer are clonal and carry a high mutation burden. J Pathol 2015;236:201-9.

15 Kurman RJ, Shih I-M. The dualistic model of ovarian carcinogenesis: revisited, revised, and expanded. Am J Pathol 2016;186:733-47.

16 Hermens M, van Altena AM, Nieboer TE, et al. Incidence of endometrioid and clear-cell ovarian cancer in histological proven endometriosis: the ENOCA population-based cohort study. Am J Obstet Gynecol 2020;223:107.e1-107.e11.

17 Stamp JP, Gilks CB, Wesseling M, et al. Baf250A expression in atypical endometriosis and endometriosis-associated ovarian cancer. Int J Gynecol Cancer 2016;26:825-32.

18 Duska LR, Garrett L, Henretta M, et al. When 'never-events' occur despite adherence to clinical guidelines: the case of venous thromboembolism in clear cell cancer of the ovary compared with other epithelial histologic subtypes. Gynecol Oncol 2010;116:374-7.

19 Recio F, Piver M, Hempling R, et al. Lack of improved survival plus increase in thromboembolic complications in patients with clear cell carcinoma. Cancer 1996;78:2157-63.

20 Matsuura Y, Robertson G, Marsden DE, et al. Thromboembolic complications in patients with clear cell carcinoma of the ovary. Gynecol Oncol 2007;104:406-10.

21 Sugiyama T, Kamura T, Kigawa J, et al. Clinical characteristics of clear cell carcinoma of the ovary. Cancer 2000;88:2584-9.

22 Takano M, Kikuchi Y, Yaegashi N, et al. Clear cell carcinoma of the ovary: a retrospective multicentre experience of 254 patients with complete surgical staging. Br J Cancer 2006;94:1369-74.

23 Suzuki S, Kajiyama H, Shibata K, et al. Is there any association between retroperitoneal lymphadenectomy and survival benefit in ovarian clear cell carcinoma patients? Ann Oncol 2008;19:1284-7.

24 Mizuno M, Kikkawa F, Shibata K, et al. Long-term prognosis of stage I ovarian carcinoma. prognostic importance of intraoperative rupture. Oncology 2003;65:29-36.

25 Hoskins PJ, Le N, Gilks B, et al. Low-stage ovarian clear cell carcinoma: population-based outcomes in British Columbia, Canada, with evidence for a survival benefit as a result of irradiation. J Clin Oncol 2012;30:1656-62.

26 Irodi A, Rye T, Herbert K, et al. Patterns of clinicopathological features and outcome in epithelial ovarian cancer patients: 35 years of prospectively collected data. BJOG 2020;65. doi:10.1111/14710528.16264. [Epub ahead of print: 13 Apr 2020].

27 Köbel M, Kalloger SE, Santos JL, et al. Tumor type and substage predict survival in stage I and II ovarian carcinoma: insights and implications. Gynecol Oncol 2010;116:50-6.

28 Vergote I, De Brabanter J, Fyles A, et al. Prognostic importance of degree of differentiation and cyst rupture in stage I invasive epithelial ovarian carcinoma. Lancet 2001;357:176-82.

29 Oliver KE, Brady WE, Birrer M, et al. An evaluation of progression free survival and overall survival of ovarian cancer patients with clear cell carcinoma versus serous carcinoma treated with platinum therapy: an NRG Oncology/Gynecologic Oncology Group experience. Gynecol Oncol 2017;147:243-9.

30 Lee Y-Y, Kim T-J, Kim M-J, et al. Prognosis of ovarian clear cell carcinoma compared to other histological subtypes: a metaanalysis. Gynecol Oncol 2011;122:541-7.

31 Winter WE, Maxwell GL, Tian C, et al. Prognostic factors for stage III epithelial ovarian cancer: a Gynecologic Oncology Group study. JCO 2007;25:3621-7.

$32 \mathrm{Liu} \mathrm{H}, \mathrm{Xu} \mathrm{Y,} \mathrm{Ji} \mathrm{J,} \mathrm{et} \mathrm{al.} \mathrm{Prognosis} \mathrm{of} \mathrm{ovarian} \mathrm{clear} \mathrm{cell} \mathrm{cancer}$ compared with other epithelial cancer types: a population-based analysis. Oncol Lett 2020;19:1947-57.

33 Hogen L, Vicus D, Ferguson SE, et al. Patterns of recurrence and impact on survival in patients with clear cell ovarian carcinoma. Int J Gynecol Cancer 2019;29:1164-9.

34 Kajiyama H, Shibata K, Mizuno M, et al. Postrecurrent oncologic outcome of patients with ovarian clear cell carcinoma. Int $J$ Gynecol Cancer 2012;22:801-6.

35 Hollis RL, Carmichael J, Meynert AM, et al. Clinical and molecular characterization of ovarian carcinoma displaying isolated lymph node relapse. Am J Obstet Gynecol 2019;221:245.e1-245.e15.

36 Lim D, Ip PPC, Cheung ANY, et al. Immunohistochemical comparison of ovarian and uterine endometrioid carcinoma, endometrioid carcinoma with clear cell change, and clear cell carcinoma. Am J Surg Pathol 2015;39:1061-9.

37 Peres LC, Cushing-Haugen KL, Anglesio M, et al. Histotype classification of ovarian carcinoma: a comparison of approaches. Gynecol Oncol 2018;151:53-60.

38 Fadare O, Parkash V. Pathology of endometrioid and clear cell carcinoma of the ovary. Surg Pathol Clin 2019;12:529-64.
39 Jones S, Wang T-L, Shih I-M, et al. Frequent mutations of chromatin remodeling gene ARID1A in ovarian clear cell carcinoma. Science 2010;330:228-31.

40 Wiegand KC, Shah SP, Al-Agha OM, et al. ARID1A mutations in endometriosis-associated ovarian carcinomas. N Engl J Med 2010;363:1532-43.

41 Itamochi $\mathrm{H}$, Oishi $\mathrm{T}$, Oumi N, et al. Whole-genome sequencing revealed novel prognostic biomarkers and promising targets for therapy of ovarian clear cell carcinoma. $\mathrm{Br} J$ Cancer 2017:117:717-24

42 Murakami R, Matsumura N, Brown JB, et al. Exome sequencing landscape analysis in ovarian clear cell carcinoma shed light on key chromosomal regions and mutation gene networks. Am J Pathol 2017;187:2246-58.

43 Wang YK, Bashashati A, Anglesio MS, et al. Genomic consequences of aberrant DNA repair mechanisms stratify ovarian cancer histotypes. Nat Genet 2017;49:856-65.

$44 \mathrm{Kim} \mathrm{SI}$, Lee JW, Lee M, et al. Genomic landscape of ovarian clear cell carcinoma via whole exome sequencing. Gynecol Oncol 2018:148:375-82.

45 Friedlander ML, Russell K, Millis S, et al. Molecular profiling of clear cell ovarian cancers: identifying potential treatment targets for clinical trials. Int J Gynecol Cancer 2016;26:648-54.

46 Kuo K-T, Mao T-L, Jones S, et al. Frequent activating mutations of PIK3CA in ovarian clear cell carcinoma. Am J Pathol 2009;174:1597-601.

47 Wilson BG, Roberts CWM. SWI/SNF nucleosome remodellers and cancer. Nat Rev Cancer 2011;11:481-92.

48 Shibuya $\mathrm{Y}$, Tokunaga $\mathrm{H}$, Saito $\mathrm{S}$, et al. Identification of somatic genetic alterations in ovarian clear cell carcinoma with next generation sequencing. Genes Chromosomes Cancer 2018;57:51-60.

49 Maru Y, Tanaka N, Ohira M, et al. Identification of novel mutations in Japanese ovarian clear cell carcinoma patients using optimized targeted NGS for clinical diagnosis. Gynecol Oncol 2017:144:377-83.

50 Samartzis E, Noske A, Dedes K, et al. ARID1A mutations and PI3K/AKT pathway alterations in endometriosis and endometriosis-associated ovarian carcinomas. Int J Mol Sci 2013;14:18824-49.

51 Takenaka M, Köbel M, Garsed DW, et al. Survival following chemotherapy in ovarian clear cell carcinoma is not associated with pathological misclassification of tumor histotype. Clin Cancer Res 2019;25:3962-73.

52 Yamamoto S, Tsuda H, Takano M, et al. Loss of ARID1A protein expression occurs as an early event in ovarian clear-cell carcinoma development and frequently coexists with PIK3CA mutations. Mod Pathol 2012;25:615-24.

53 Huang $\mathrm{H}-\mathrm{N}$, Lin M-C, Huang W-C, et al. Loss of ARID1A expression and its relationship with PI3K-AKT pathway alterations and ZNF217 amplification in ovarian clear cell carcinoma. Mod Pathol 2014:27:983-90.

54 Arildsen NS, Jönsson J-M, Bartuma K, et al. Involvement of chromatin remodeling genes and the Rho GTPases $R$ hoB and CDC42 in ovarian clear cell carcinoma. Front Oncol 2017;7:109.

55 Elvin JA, Chura J, Gay LM, et al. Comprehensive genomic profiling (CGP) of ovarian clear cell carcinomas (OCCC) identifies clinically relevant genomic alterations (CRGA) and targeted therapy options. Gynecol Oncol Rep 2017;20:62-6.

56 Chandler RL, Damrauer JS, Raab JR, et al. Coexistent ARID1APIK3CA mutations promote ovarian clear-cell tumorigenesis through pro-tumorigenic inflammatory cytokine signalling. Nat Commun 2015;6:6118.

57 McConechy MK, Anglesio MS, Kalloger SE, et al. Subtype-specific mutation of PPP2R1A in endometrial and ovarian carcinomas. $J$ Pathol 2011;223:567-73.

58 Yamashita Y, Akatsuka S, Shinjo K, et al. Met is the most frequently amplified gene in endometriosis-associated ovarian clear cell adenocarcinoma and correlates with worsened prognosis. PLoS One 2013;8:e57724.

59 Yamamoto S, Tsuda H, Miyai K, et al. Gene amplification and protein overexpression of Met are common events in ovarian clear-cell adenocarcinoma: their roles in tumor progression and prognostication of the patient. Mod Pathol 2011;24:1146-55.

60 Sugino K, Tamura R, Nakaoka H, et al. Germline and somatic mutations of homologous recombination-associated genes in Japanese ovarian cancer patients. Sci Rep 2019;9:17808.

61 RC W, Ayhan A, Maeda D, et al. Frequent somatic mutations of the telomerase reverse transcriptase promoter in ovarian clear cell carcinoma but not in other major types of gynaecological malignancy. J Pathol 2014;232:473-81. 
62 Huang $\mathrm{H}-\mathrm{N}$, Chiang Y-C, Cheng W-F, et al. Molecular alterations in endometrial and ovarian clear cell carcinomas: clinical impacts of telomerase reverse transcriptase promoter mutation. Mod Pathol 2015;28:303-11.

63 Swanton C, McGranahan N, Starrett GJ, et al. Apobec enzymes: mutagenic fuel for cancer evolution and heterogeneity. Cancer Discov 2015;5:704-12.

64 Serebrenik AA, Argyris PP, Jarvis MC, et al. The DNA cytosine deaminase APOBEC3B is a molecular determinant of platinum responsiveness in clear cell ovarian cancer. Clin Cancer Res 2020;26:3397-407.

65 Kuo K-T, Mao T-L, Chen X, et al. DNA copy numbers profiles in affinity-purified ovarian clear cell carcinoma. Clin Cancer Res 2010;16:1997-2008.

66 Uehara Y, Oda K, Ikeda Y, et al. Integrated copy number and expression analysis identifies profiles of whole-arm chromosomal alterations and subgroups with favorable outcome in ovarian clear cell carcinomas. PLoS One 2015;10:e0128066.

67 Okamoto A, Sehouli J, Yanaihara N, et al. Somatic copy number alterations associated with Japanese or endometriosis in ovarian clear cell adenocarcinoma. PLoS One 2015;10:e0116977.

68 Rahman MT, Nakayama K, Rahman M, et al. Prognostic and therapeutic impact of the chromosome 20q13.2 ZNF217 locus amplification in ovarian clear cell carcinoma. Cancer 2012;118:2846-57.

69 Tan DSP, Iravani M, McCluggage WG, et al. Genomic analysis reveals the molecular heterogeneity of ovarian clear cell carcinomas. Clin Cancer Res 2011;17:1521-34.

70 Abou-Taleb H, Yamaguchi K, Matsumura N, et al. Comprehensive assessment of the expression of the SWI/SNF complex defines two distinct prognostic subtypes of ovarian clear cell carcinoma. Oncotarget 2016;7:54758-70.

71 Schwartz DR, Kardia SLR, Shedden KA, et al. Gene expression in ovarian cancer reflects both morphology and biological behavior, distinguishing clear cell from other poor-prognosis ovarian carcinomas. Cancer Res 2002;62:4722-9.

72 Zorn KKet al. Gene expression profiles of serous, endometrioid, and clear cell subtypes of ovarian and endometrial cancer. Clin Cancer Res 2005;11:6422-30.

73 Tsuchiya A, Sakamoto M, Yasuda J, et al. Expression profiling in ovarian clear cell carcinoma: identification of hepatocyte nuclear factor-1 beta as a molecular marker and a possible molecular target for therapy of ovarian clear cell carcinoma. Am J Pathol 2003;163:2503-12.

74 Yamaguchi K, Mandai M, Toyokuni S, et al. Contents of endometriotic cysts, especially the high concentration of free iron, are a possible cause of carcinogenesis in the cysts through the iron-induced persistent oxidative stress. Clin Cancer Res 2008;14:32-40.

75 Tan TZ, Ye J, Yee CV, et al. Analysis of gene expression signatures identifies prognostic and functionally distinct ovarian clear cell carcinoma subtypes. EBioMedicine 2019;50:203-10.

76 Takano M, Sugiyama T, Yaegashi N, et al. The impact of complete surgical staging upon survival in early-stage ovarian clear cell carcinoma: a multi-institutional retrospective study. Int J Gynecol Cancer 2009;19:1353-7.

77 Kleppe M, Wang T, Van Gorp T, et al. Lymph node metastasis in stages I and II ovarian cancer: a review. Gynecol Oncol 2011;123:610-4.

78 Mahdi H, Moslemi-Kebria M, Levinson KL, et al. Prevalence and prognostic impact of lymphadenectomy and lymph node metastasis in clinically early-stage ovarian clear cell carcinoma. Int J Gynecol Cancer 2013;23:1226-30.

79 Magazzino F, Katsaros D, Ottaiano A, et al. Surgical and medical treatment of clear cell ovarian cancer: results from the Multicenter Italian Trials in Ovarian Cancer (MITO) 9 retrospective study. Int J Gynecol Cancer 2011;21:1063-70.

80 Chi DS, Eisenhauer EL, Lang J, et al. What is the optimal goal of primary cytoreductive surgery for bulky stage IIIC epithelial ovarian carcinoma (EOC)? Gynecol Oncol 2006;103:559-64.

81 Eisenhauer EL, Abu-Rustum NR, Sonoda Y, et al. The effect of maximal surgical cytoreduction on sensitivity to platinum-taxane chemotherapy and subsequent survival in patients with advanced ovarian cancer. Gynecol Oncol 2008;108:276-81.

82 Winter WE, Maxwell GL, Tian C, et al. Tumor residual after surgical cytoreduction in prediction of clinical outcome in stage IV epithelial ovarian cancer: a Gynecologic Oncology Group study. J Clin Oncol 2008;26:83-9.

83 Melamed A, Manning-Geist B, Bregar AJ, et al. Associations between residual disease and survival in epithelial ovarian cancer by histologic type. Gynecol Oncol 2017;147:250-6.
84 Kajiyama $\mathrm{H}$, Shibata $\mathrm{K}$, Mizuno M, et al. Fertility-sparing surgery in patients with clear-cell carcinoma of the ovary: is it possible? Hum Reprod 2011;26:3297-302.

85 Satoh T, Yoshikawa H. Fertility-sparing surgery for early stage epithelial ovarian cancer. Jpn J Clin Oncol 2016;46:703-10.

86 Nasioudis D, Mulugeta-Gordon L, McMinn E, et al. Fertility sparing surgery for patients with FIGO stage I clear cell ovarian carcinoma: a database analysis and systematic review of the literature. Int $J$ Gynecol Cancer 2020;30:1372-7.

87 National Comprehensive Cancer Network. NCCN guidelines version 1.2020 ovarian cancer, 2020. Available: https://www.nccn. org/professionals/physician_gls/default.aspx\#ovarian [Accessed 10 Aug 2020].

88 Morgan RJ, Armstrong DK, Alvarez RD, et al. Ovarian cancer, version 1.2016, NCCN clinical practice guidelines in oncology. $J$ Natl Compr Canc Netw 2016;14:1134-63.

89 Colombo N, Sessa C, du Bois A, et al. ESMO-ESGO consensus conference recommendations on ovarian cancer: pathology and molecular biology, early and advanced stages, borderline tumours and recurrent diseaset. Ann Oncol 2019;30:672-705.

90 Timmers PJ, Zwinderman AH, Teodorovic I, et al. Clear cell carcinoma compared to serous carcinoma in early ovarian cancer: same prognosis in a large randomized trial. Int J Gynecol Cancer 2009;19:88-93.

91 Mizuno M, Kajiyama $\mathrm{H}$, Shibata $\mathrm{K}$, et al. Adjuvant chemotherapy for stage I ovarian clear cell carcinoma: is it necessary for stage la? Int J Gynecol Cancer 2012;22:1143-9.

92 Takada $\mathrm{T}$, Iwase $\mathrm{H}$, litsuka $\mathrm{C}$, et al. Adjuvant chemotherapy for stage I clear cell carcinoma of the ovary: an analysis of fully staged patients. Int J Gynecol Cancer 2012;22:573-8.

93 Oseledchyk A, Leitao MM, Konner J, et al. Adjuvant chemotherapy in patients with stage I endometrioid or clear cell ovarian cancer in the platinum era: a surveillance, epidemiology, and end results cohort study, 2000-2013. Ann Oncol 2017;28:2985-93.

94 Bogani G, Ditto A, Lopez S, et al. Adjuvant chemotherapy vs. observation in stage I clear cell ovarian carcinoma: a systematic review and meta-analysis. Gynecol Oncol 2020;157:293-8.

95 Prendergast EN, Holzapfel M, Mueller JJ, et al. Three versus six cycles of adjuvant platinum-based chemotherapy in early stage clear cell ovarian carcinoma - a multi-institutional cohort. Gynecol Oncol 2017;144:274-8.

96 Utsunomiya H, Akahira J, Tanno S, et al. Paclitaxel-platinum combination chemotherapy for advanced or recurrent ovarian clear cell adenocarcinoma: a multicenter trial. Int $J$ Gynecol Cancer 2006;16:52-6.

97 Takano M, Tsuda H, Sugiyama T. Clear cell carcinoma of the ovary: is there a role of histology-specific treatment? J Exp Clin Cancer Res 2012;31.

98 Goff BA, Sainz de la Cuesta R, Muntz HG, et al. Clear cell carcinoma of the ovary: a distinct histologic type with poor prognosis and resistance to platinum-based chemotherapy in stage III disease. Gynecol Oncol 1996;60:412-7.

99 Ho C-M, Huang Y-J, Chen T-C, et al. Pure-type clear cell carcinoma of the ovary as a distinct histological type and improved survival in patients treated with paclitaxel-platinum-based chemotherapy in pure-type advanced disease. Gynecol Oncol 2004;94:197-203.

100 Katsumata N, Yasuda M, Isonishi S, et al. Long-term results of dose-dense paclitaxel and carboplatin versus conventional paclitaxel and carboplatin for treatment of advanced epithelial ovarian, fallopian tube, or primary peritoneal cancer (JGOG 3016): a randomised, controlled, open-label trial. Lancet Oncol 2013;14:1020-6.

101 Adachi S, Ogasawara T, Yamasaki N, et al. A pilot study of CPT-11 and cisplatin for ovarian clear cell adenocarcinoma. Jpn J Clin Oncol 1999;29:434-7.

102 Kita T, Kikuchi Y, Kudoh K, et al. Exploratory study of effective chemotherapy to clear cell carcinoma of the ovary. Oncol Rep 2000;7:327-31.

103 Takakura S, Takano M, Takahashi F, et al. Randomized phase II trial of paclitaxel plus carboplatin therapy versus irinotecan plus cisplatin therapy as first-line chemotherapy for clear cell adenocarcinoma of the ovary: a JGOG study. Int J Gynecol Cancer 2010;20:240-7.

104 Sugiyama T, Okamoto A, Enomoto T, et al. Randomized phase III trial of irinotecan plus cisplatin compared with paclitaxel plus carboplatin as first-line chemotherapy for ovarian clear cell carcinoma: JGOG3017/GCIG trial. J Clin Oncol 2016;34:2881-7.

105 Crotzer DR, Sun CC, Coleman RL, et al. Lack of effective systemic therapy for recurrent clear cell carcinoma of the ovary. Gynecol Oncol 2007;105:404-8. 


\section{Review}

106 Takano M, Sugiyama T, Yaegashi N, et al. Low response rate of second-line chemotherapy for recurrent or refractory clear cell carcinoma of the ovary: a retrospective Japan Clear Cell Carcinoma Study. Int J Gynecol Cancer 2008;18:937-42.

107 Sugiyama T, Yakushiji M, Nishida T, et al. Irinotecan (CPT-11) combined with cisplatin in patients with refractory or recurrent ovarian cancer. Cancer Lett 1998;128:211-8.

108 Yoshino K, Enomoto T, Fujita M, et al. Salvage chemotherapy for recurrent or persistent clear cell carcinoma of the ovary: a singleinstitution experience for a series of 20 patients. Int $\mathrm{J}$ Clin Oncol 2013;18:148-53.

109 Parmar MKB, Ledermann JA, Colombo N, et al. Paclitaxel plus platinum-based chemotherapy versus conventional platinum-based chemotherapy in women with relapsed ovarian cancer: the ICON4/ AGO-OVAR-2.2 trial. Lancet 2003;361:2099-106.

110 Nagai Y, Inamine M, Hirakawa M, et al. Postoperative whole abdominal radiotherapy in clear cell adenocarcinoma of the ovary. Gynecol Oncol 2007;107:469-73.

111 Hogen L, Thomas G, Bernardini M, et al. The effect of adjuvant radiation on survival in early stage clear cell ovarian carcinoma. Gynecol Oncol 2016;143:258-63.

112 Komura N, Mabuchi S, Isohashi F, et al. Radiotherapy for isolated recurrent epithelial ovarian cancer: a single institutional experience. J Obstet Gynaecol Res 2019;45:1173-82.

113 Chang JS, Kim SW, Kim Y-J, et al. Involved-field radiation therapy for recurrent ovarian cancer: results of a multi-institutional prospective phase II trial. Gynecol Oncol 2018;151:39-45.

114 Brown AP, Jhingran A, Klopp AH, et al. Involved-field radiation therapy for locoregionally recurrent ovarian cancer. Gynecol Oncol 2013;130:300-5.

115 Oza AM, Cook AD, Pfisterer J, et al. Standard chemotherapy with or without bevacizumab for women with newly diagnosed ovarian cancer (ICON7): overall survival results of a phase 3 randomised trial. Lancet Oncol 2015;16:928-36.

116 Chan JK, Brady W, Monk BJ, et al. A phase II evaluation of sunitinib in the treatment of persistent or recurrent clear cell ovarian carcinoma: an NRG Oncology/Gynecologic Oncology Group study (GOG-254). Gynecol Oncol 2018;150:247-52.

117 Farley JH, Brady WE, Fujiwara K, et al. A phase II evaluation of temsirolimus in combination with carboplatin and paclitaxel followed by temsirolimus consolidation as first-line therapy in the treatment of stage III-IV clear cell carcinoma of the ovary. J Clin Oncol 2016;34:5531.
118 Hamanishi J, Mandai M, Ikeda T, et al. Safety and antitumor activity of anti-PD-1 antibody, nivolumab, in patients with platinumresistant ovarian cancer. J Clin Oncol 2015;33:4015-22.

119 Disis ML, Patel MR, Pant S, et al. Avelumab (MSB0010718C; antiPD-L1) in patients with recurrent/refractory ovarian cancer from the JAVELIN Solid Tumor phase Ib trial: safety and clinical activity. $J$ Clin Oncol 2016;34:5533.

120 Lheureux S, Tinker A, Clarke B, et al. A clinical and molecular phase II trial of oral ENMD-2076 in ovarian clear cell carcinoma (OCCC): a study of the Princess Margaret Phase II Consortium. Clin Cancer Res 2018;24:clincanres.1244.2018-74.

121 Bitler BG, Wu S, Park PH, et al. ARID1A-mutated ovarian cancers depend on HDAC6 activity. Nat Cell Biol 2017;19:962-73.

122 Bitler BG, Aird KM, Garipov A, et al. Synthetic lethality by targeting EZH2 methyltransferase activity in ARID1A-mutated cancers. Nat Med 2015;21:231-8.

123 Yano M, Katoh T, Miyazawa M, et al. Clinicopathological correlation of ARID1A status with HDAC6 and its related factors in ovarian clear cell carcinoma. Sci Rep 2019;9:2397.

124 Fukumoto T, Fatkhutdinov N, Zundell JA, et al. HDAC6 inhibition synergizes with anti-PD-L1 therapy in ARID1A-Inactivated ovarian cancer. Cancer Res 2019;79:5482-9.

125 Price C, Gill S, Ho ZV, et al. Genome-wide interrogation of human cancers identifies EGLN1 dependency in clear cell ovarian cancers. Cancer Res 2019;79:2564-79.

126 Kuroda T, Ogiwara H, Sasaki M, et al. Therapeutic preferability of gemcitabine for ARID1A-deficient ovarian clear cell carcinoma. Gynecol Oncol 2019;155:489-98.

127 Caumanns JJ, Berns K, Wisman GBA, et al. Integrative kinome profiling identifies mTORC1/2 inhibition as treatment strategy in ovarian clear cell carcinoma. Clin Cancer Res 2018;24:3928-40.

128 Caumanns JJ, Wisman GBA, Berns K, et al. ARID1A mutant ovarian clear cell carcinoma: a clear target for synthetic lethal strategies. Biochim Biophys Acta Rev Cancer 2018;1870:176-84.

129 del Carmen MG, Birrer M, Schorge JO. Clear cell carcinoma of the ovary: a review of the literature. Gynecol Oncol 2012;126:481-90.

130 Nishikimi K, Nakagawa K, Tate S, et al. Uncommon human telomerase reverse transcriptase promoter mutations are associated with poor survival in ovarian clear cell carcinoma. Am J Clin Pathol 2018;149:352-61.

131 Mabuchi S, Sugiyama T, Kimura T. Clear cell carcinoma of the ovary: molecular insights and future therapeutic perspectives. $J$ Gynecol Oncol 2016;27:e31. 